\title{
The Long Haul: The Evolution and Development of an Independent South African Navy
}

\section{Allan du Toit}

\begin{abstract}
Peu de temps après la création de l'Union de l'Afrique du Sud en 1910, une division sud-africaine de la Réserve volontaire de la marine royale a été instituée, ses membres servant dans tous les théâtres de la Première Guerre mondiale. Un petit service naval a été constitué en 1922, mais a pratiquement disparu dans les années 1930 en raison de la rigueur financière. Le déclenchement de la Seconde Guerre mondiale a relancé le service et pendant la guerre froide, la marine sud-africaine a connu une période de croissance importante, car elle a pris de plus en plus de responsabilités en matière de la protection vitale de la voie maritime du Cap. Cependant, la politique d'apartheid de l'Afrique du Sud, a rapidement conduit à l'isolement de plus en plus marqué de la marine sud-africaine, qui, tout en protégeant son propre existence, a perdu sa capacité en haute mer au milieu des années 1980. Tout cela a changé dès l'arrivée de gouvernement démocratique en 1994. L'Afrique du Sud a rétabli, une fois de plus, une flotte équilibrée, en assumant un rôle de plus en plus prépondérant en Afrique subsaharienne.
\end{abstract}

Modern South Africa, with its important geostrategic position and reliance on maritime trade, owes its existence to the sea. The Cape was discovered by seaborne explorers, the first permanent European settlement established by the Dutch East India Company in 1652 had as its purpose the support of ships, and the sub-continent's only contact with the rest of the world for the next three centuries was by sea.

With the outbreak of the revolutionary wars in Europe, Britain decided that the Cape was too valuable to fall into French hands. When negotiations with the Cape's Dutch rulers failed, a British expedition was despatched to occupy the Cape, which capitulated in September 1795. Although the Colony was returned to Dutch rule at the Peace of Amiens in 1803, the renewal of hostilities with the French necessitated a second British conquest, and in 1806 Dutch government at the Cape was permanently ended.

Throughout the nineteenth century the Royal Navy's supremacy in the Indian Ocean remained unchallenged, and as trade between Europe and the East significantly increased, the ports of the Cape Colony and later the Natal Colony shared in the new prosperity. Even the opening of the Suez Canal had only a slight effect on the amount of

The Northern Mariner/Le marin du nord XXIV, Nos. 3 \& 4 (Jul. \& Oct. 2014), 82-103 Canadian Military History 23, Nos. 3 \& 4 (Summer \& Autumn 2014), 82-103 
shipping using these ports, which continued to prosper. The colonists, however, whether under Dutch or British rule, showed little interest in maritime affairs beyond the benefits which seaborne traffic brought them. It is not surprising therefore that South Africa's first indigenous naval units were firmly shore-based.

\section{Beginnings}

The South African Navy's earliest beginnings can be traced back to the formation of a short-lived small volunteer naval force at Port Elizabeth in the Cape Colony in 1861. More than twenty years passed before a second part-time naval unit, the Natal Naval Volunteers (NNV), was formed in the Natal Colony during a period of rising tensions between Great Britain and Russia over Afghanistan. Although members of the NNV served ashore as gunners with the British Naval Brigade Field Force in the South African War (1899-1902), the unit had no specific naval commitments, as the seaward defence of the South African colonies remained exclusively with the imperial government. ${ }^{1}$

Although a small volunteer naval unit, the Sailors' Company of the Cape Town Guard, was briefly raised during the closing stages of the South African War, it was not until 1905 that a fully fledged naval volunteer unit, the Cape Naval Volunteers (CNV), was established in Cape Town. The idea of establishing a naval volunteer unit at the Cape followed the establishment of the Royal Naval Volunteer Reserve (RNVR) in Great Britain in $1903 .{ }^{2}$ However, both the NNV and CNV were merely sections of the local defence organisation in both colonies.

With the concurrence of the Board of Admiralty, both the Natal and Cape Parliaments passed almost identical acts in 1907 and 1908 respectively, providing for the official creation of the Cape and Natal Colonial Divisions of the RNVR. Although the British Parliament sanctioned both acts in 1909, further local development was delayed by political preoccupation with the unification of the four South African colonies.

In addition to the formation of volunteer naval units, both the Cape and Natal colonial governments made annual contributions towards the upkeep of the Royal Navy. The Natal government also made available to the Royal Navy supplies of the best Natal coal, while the Cape Colonial government passed the Simon's Town Naval Defence Act in 1898 which authorised the development of the port as a major naval base for the Royal Navy on the important Cape sea route. The extensive new dockyard which included a graving dock and sheltered tidal basin was finally completed in 1910, and became the principal harbour for the vessels of the Royal Navy Cape of Good Hope and West Coast of Africa Station.

1 In researching this paper the author has drawn extensively on his previously published work, South Africa's Fighting Ships (Rivonia: Ashanti Publishing, 1992), and wishes to acknowledge the three other standard authoritative texts on the South African Navy: A.P. Burgers. A Short History of the South African Navy (Simon's Town: SA Navy, 1967); J.C. Goosen, South Africa's Navy The First Fifty Years (Cape Town: W.J. Flesch and Partners, 1973); and the more recent C.H. Bennett \& A.G. Söderlund, South Africa's Navy (Simon's Town: SA Navy, 2008).

2 Burgers, A Short History of the South African Navy, 5. 
When the Union of South Africa finally came into being on 31 May 1910, both colonial naval volunteer acts were placed in abeyance as the newly formed Union government was not prepared to continue with the formation of RNVR divisions until it was ready to place its defence arrangements before the Union Parliament. The new Union government continued, however, to meet the former colonies' financial obligations towards the naval defence of both the Union and wider empire. With the passing of the South African Defence Act of 1912, the two naval volunteer units were finally amalgamated by statute to form the South African Division of the Royal Naval Volunteer Reserve (RNVR(SA)) with companies at Cape Town and Durban.

The new Division, which was to be placed at the disposal of the British Admiralty in time of war, officially came into being on 1 July 1913 in pursuance of an Order-in-Council by HM King George V. Although funded by the South African Parliament, and constitutionally part of the Union Defence Force, the Admiralty (through the Royal Navy Commander-in-Chief, Cape of Good Hope Station) assumed responsibility for the Division's peacetime organisation, training, administration and discipline, subject only to the Union government's approval in matters of principle. ${ }^{3}$

Shortly before the outbreak of the First World War, discussions were held with the British Admiralty as to the best way the Union of South Africa could serve the interests of imperial defence at sea. As there were a number of officers and ratings of South African birth serving in the Royal Navy at that time, the Minister of Defence, General J.C. Smuts, suggested to the Admiralty that a flotilla of torpedo boat destroyers and submarines, manned as far as possible by those South Africans, should be stationed in South African waters for the defence of the Union's coast. His proposal envisaged that the South African government would be responsible for all the costs associated with the maintenance of the flotilla, which he hoped would give birth to an indigenous South African navy, similar to those already in being in Australia and Canada. The proposal was not favoured by the Admiralty and informal discussions were still in progress when war broke out in 1914. (Readers will recall from previous chapters that Admiralty thinking at the time was focussed on the formation by the dominions of Fleet Units, centred on a battlecruiser, to prosecute operations against commerce raiders should war with Germany eventuate.) With more important matters on hand, the proposal was dropped and South Africa entered the war without warships which she could in any way call her own. ${ }^{4}$

\section{The First World War}

With the outbreak of war, a number of South African registered vessels and ships operating in Union waters were taken-up by the Admiralty for war service. Although South Africa had a small but highly enthusiastic body of volunteers to contribute to the naval effort against Germany, the Royal Navy was expected to protect South Africa. The RNVR(SA) was immediately mobilised without proclamation and was able to place 12

3 See Serald Hay, History of the RNVR South African Division (Cape Town, Juta \& Co, 1920).

4 Burgers, A Short History of the South African Navy, 7. 
officers and 267 men at the disposal of the British Admiralty within 24 hours of receiving orders on 3 August. Members of the Division subsequently served at sea and ashore both locally and during the South West African and East African campaigns, including the destruction of the German cruiser Konigsberg in the Rufiji river delta in German East Africa. ${ }^{5}$

With the successful conclusion of the campaign in South West Africa and the surrender of the territory in July 1915, the RNVR(SA) was partially demobilised during August 1915, and its members given the opportunity to volunteer for service with the Royal Navy in the European and Mediterranean theatres. The response was enthusiastic and the first contingent sailed from Cape Town on 9 October 1915. They were later followed by three further contingents between May 1916 and September 1917.

Members of the Division served overseas with the Royal Navy in almost every theatre of war, both ashore and afloat. South African sailors served in the ships of the Grand Fleet and the Harwich force, whilst a small number also took part in the Dardanelles campaign. At home, members of the Division served in vessels taken up by the Admiralty for war service, including minesweeping operations in Cape waters after the armed German raider Wolf laid mines in the approaches to Table Bay and in the shipping routes off Cape Agulhas in early 1917.

After the signing of the Armistice on 11 November 1918, all RNVR(SA) personnel serving in South Africa were demobilised, whilst those serving overseas were progressively demobilised upon their return to the Union. With the return of peace, all vessels requisitioned by the Admiralty in South African waters were either sold or returned to their owners and the RNVR(SA), which had won its spurs in no uncertain manner, reverted to its peacetime organisation. South Africa, however, remained entirely dependent on the Royal Navy for the protection of its commerce and shores and, as was the case at the outset of hostilities, the Union still had no fighting ships of her own.

\section{Between the Wars}

Although the South African Prime Minister, General Louis Botha, returned from the Versailles Peace Conference in 1919 determined that South Africa should have its own full-time naval service, it was not until January 1922 that a small nascent force became a reality, with the arrival of the country's first naval vessels from Britain.

The acquisition of these ships by the South African government stemmed from the Imperial Conference held in London in mid-1921. At this Conference, Union Prime Minister General J.C. Smuts and the British government agreed to discontinue South Africa's outmoded annual contribution towards the running of the Royal Navy, and decided instead that, like the other dominions, South Africa would establish the nucleus of a permanent seagoing naval force. ${ }^{6}$

Although Admiral of the Fleet Lord Jellicoe had recommended that South Africa should provide and maintain a squadron to keep open the trade route round the Cape,

5 du Toit, South Africa's Fighting Ships, xxii.

6 Goosen, South Africa's Navy The First Fifty Years, 12. 
General Smuts considered this to be beyond the Union's limited human and financial resources. As a result, the Union Government undertook to expand the RNVR(SA), including the formation of a minesweeping section. In addition to this it also agreed to assume responsibility for the hydrographic survey of its own waters and to bear a portion of the costs of further developing the Simon's Town naval dockyard to which the Admiralty had "the right of perpetual use for naval purposes."7 In essence, hydrographic survey was to become the principal peacetime function of the new service.

In view of this decision, the British Admiralty dropped its earlier plans to transfer a light cruiser and escort vessels to South Africa, and agreed instead to make available a twin screw Later Hunt-class minesweeper which had been completed as a survey vessel, and two Mersey-class Admiralty minesweeping trawlers.

To man these vessels, a new arm of the Union Defence Force (UDF), the South African Naval Service (SANS), was established on 1 April 1922, and formally integrated as a permanent unit of the UDF from 1 February 1923. The new service, which numbered sixteen officers and 117 ratings, was placed under the command of Commander N.H. Rankin, a retired Royal Navy officer, who was also the InstructorCommander for the RNVR(SA). Although a large proportion of the personnel in the new service were on loan from the Royal Navy, South Africa's own navy was at last a reality.

At the same time the RNVR(SA) was expanded to man local defence flotillas and other similar services in time of war. ${ }^{8}$ In July 1921 two additional RNVR(SA) units were established at East London and Port Elizabeth. These units, together with those at Cape Town and Durban, were subsequently responsible for training sufficient men to man three general service divisions and three minesweeping flotillas, comprising 36 officers and 600 ratings.

Sadly, the SANS, now headed by Commander R.F.U.P Fitzgerald RN, was not destined to last for long. As a result of the Wall Street crash of 1929, which heralded the great depression of the 1930s, Union defence expenditure was severely cut back, South Africa's infant navy being the main victim. The appointment of Officer Commanding SANS was discontinued on 4 November 1932, and the command and administration of the SANS and RNVR(SA) once again reverted to the Royal Navy's Commander-in-Chief Africa Station. Lengthy discussions about the future of the service followed, which resulted in the survey ship His Majesty's South African Ship (HMSAS) Protea being paid-off and the establishment of the SANS reduced from 164 officers and ratings to 56 from 1 May 1933. Although the two minesweepers remained in commission with reduced crews for a further year to continue minesweeping training for the RNVR(SA), they were finally returned to the Royal Navy in April 1934, and all but a handful of personnel were paid-off.

Although the SANS disappeared as a seagoing force, a small core element consisting of four officers and 12 ratings under the control of the Staff Officer SANS, supported by a staff of ten civilians, was retained. Their task was to continue the

7 du Toit, South Africa's Fighting Ships, 3.

8 Bennett \& Söderlund, South Africa's Navy, 17. 
hydrographic survey of South African waters in conjunction with the Department of Sea Fisheries using the fishery research ship Africana, and for administering and training the RNVR(SA) which fortunately continued to operate in the years leading up to the Second World War.

\section{The Second World War}

Five years after the disposal of the vessels of the SANS, South Africa once again found itself at war. As was the case at the outbreak of war in 1914, the Union was almost entirely bereft of adequate indigenous maritime defences, with the long South African coastline open and largely undefended. Although the SANS still existed, with three officers and three ratings on strength, once again the nation did not have a single warship of its own, with the seaward defence of the country and the protection of South Africa's trade on the high seas in the hands of the Royal Navy which was urgently required elsewhere.

The Admiralty's war plan, based on experience gained during the First World War, made provision for port minesweepers, anti-submarine vessels and examination craft manned principally by the RNVR(SA) to be based at the major South African ports. A number of local trawlers, whale-catchers and other small vessels which had previously been surveyed were quickly requisitioned and readied for war service. The first three minesweepers were ready by 15 September 1939, and by the end of December there were fifteen converted minesweepers in service. Whilst the RNVR(SA) was not mobilised, the Union Government gave permission for volunteers to serve locally with the Royal Navy, and in limited numbers overseas.

The War was still in its infancy when the South African government decided that the Union Defence Force should be responsible for local seaward defence as the Royal Navy would be unable to provide more than a few warships to operate occasionally in South African waters. Although the Senior Naval Officer Simon's Town wrote to the Secretary for Defence and pointed out that the efficient handling of the war at sea required a single control of naval forces in South African waters by himself, Prime Minister General Smuts approached Rear-Admiral G.W. Hallifax, CMG, a retired Royal Navy officer living in South Africa and who had been Secretary to the Governor-General, to head the reinvigorated SANS. After it was discovered that the RNVR(SA) could not legally be transferred to the new command, as it had been constituted by an act of Parliament, it became necessary to establish a new unit called the Seaward Defence Force (SDF). At the same time, the South African Air Force (SAAF) established the nucleus of a Coastal Command which steadily expanded as the war progressed. ${ }^{9}$

The SDF, like its predecessor the SANS, was to have a difficult start. In addition to the more usual problems of establishing any new organisation, Hallifax had to battle with the perennial problem that has faced the South African Navy until fairly recent

9 L.C.F. Turner, H.R. Gordon-Cumming \& J.E. Betzler, War in the Southern Oceans (Cape Town: Oxford University Press, 1961), 18. 
times: a complete lack of naval understanding at Defence Headquarters in Pretoria. ${ }^{10}$ Admiral Hallifax's naval and diplomatic ability, together with his optimism, resourcefulness and relative independence, enabled him to ensure that the second attempt by South Africa to establish a navy did not fail. ${ }^{11}$

The first task facing the SDF was to acquire ships and train men as quickly as possible in order to meet its commitments to counter the growing German submarine and mine threat in southern waters. A large measure of assistance was rendered by the Royal Navy during the formation of the SDF, and the force took over most of the vessels which had been requisitioned locally by the Admiralty. The Royal Navy also agreed to release a number of retired RN personnel resident in South Africa and some members of the RNVR(SA) to serve in the new force. The five remaining permanent members of the SANS, together with the SANS War Reserve, were also transferred to the SDF.

The SDF assumed responsibility for minesweeping duties and anti-submarine patrols in the approaches to South Africa's major ports and took over the port war signal stations, merchant ship examination services and naval control of shipping offices in each South African port. When it formally came into existence on 15 January 1940, the SDF comprised 17 requisitioned ships (15 minesweepers and two examination vessels) and was manned by 74 officers and 358 ratings. Of these, 36 officers and 182 men were volunteers on loan from the RNVR(SA), which continued to exist as an independent organisation under South African control to provide manpower for the Royal Navy. From that time, all commissioned ships and establishments of the new SDF were designated HMSA Ships, as had been the practice in the pre-war SA Naval Service.

In May 1940 the new SDF was engaged in the arduous task of clearing mines laid by the German commerce raider Atlantis in the main shipping route near Cape Agulhas at the southern extremity of the African continent. The Agulhas mining incident, more than any other, was to bring home to the Union Government and defence hierarchy the need for more than harbour protection forces and the SDF began a process of expansion that was to continue for the rest of the war. ${ }^{12}$ By October 1940 the SDF had grown in strength to 183 officers and 1,049 ratings, and by December there were 24 minesweepers in commission in addition to the eight converted anti-submarine whalers and trawlers. Moreover, in the course of the next two years a further 12 anti-submarine vessels and 13 minesweepers were brought into service. ${ }^{13}$

Following Italy's entry into the war, the submarine threat to shipping in southern waters became of grave concern as it was known that six large Italian submarines, capable of operating south of Durban, were stationed at Massawa in Italian Eritrea on the Red Sea. As a result the SDF detachment in Durban was increased with the addition of two anti-submarine vessels, and the detachment was further expanded after the attack on

10 Bennett \& Söderlund, South Africa's Navy, 21.

11 W.M. Bisset, “Admiral Hallifax Centenary,” in SA Navy News, Vol III No 71984 (Simon's Town, SA Navy), 6.

12 Bennett \& Söderlund, South Africa's Navy, 22.

13 Du Toit, South Africa's Fighting Ships, 28. 
Pearl Harbor when Japan entered the war.

The activities of the SDF were not confined to South African waters. Less than a year after its formation, the new service extended its operations far beyond local waters. In response to an urgent request from the Admiralty, a flotilla of anti-submarine vessels sailed for the eastern Mediterranean to join the British Mediterranean Fleet. The number of South African ships in the Mediterranean steadily increased, reaching a peak of four anti-submarine vessels, eight magnetic minesweepers and a salvage vessel. In addition to their brave exploits on the supply run to the besieged troops at Tobruk, South African vessels in the Mediterranean theatre also played a notable part in later operations along the North African and Levant coasts and in the final phase of the Italian and Adriatic campaigns. Four South African ships were lost through enemy action in the Mediterranean.

The tragic death of Admiral Hallifax in an air crash in March 1941 dealt a serious blow to the Navy in its early formative years. In replacement, his deputy, Commander James Dalgleish, was promoted to the rank of captain and appointed Director SDF. The very capable Scottish-born Dalgleish had served in the Royal Navy during the First World War and came to South Africa on temporary service in 1920 as navigator of the government fishery survey vessel Pickle. He subsequently transferred to the hydrographic section of the newly formed SANS in 1922 and served continuously from that time, becoming the first South African Hydrographer. The task now facing Dalgleish, of completing the programme of creating and expanding the SDF, was a formidable one. Throughout the remaining war years, he ably led South Africa's fledgling navy with absolute dedication and with dour Scottish determination and fortitude. ${ }^{14}$

On 1 August 1942 the rapidly growing SDF and the RNVR(SA) (which had grown to unprecedented levels) were amalgamated to form the South African Naval Forces (SANF). From that date, all members of the RNVR(SA) serving with the Royal Navy throughout the world, became seconded members of the new SANF. ${ }^{15}$ The original functions of the SANF widened and became more varied as the war progressed. Following the fall of France and Italy's entry into the war, the conflicts in Abyssinia and the Western Desert escalated, and the Cape sea route became of vital importance to the Allied cause after the Mediterranean shipping routes between Gibraltar and Suez were severely disrupted. ${ }^{16}$

The submarine threat in South African waters did not become a serious problem until October 1942, when the enemy launched widespread submarine attacks on shipping using the routes round the Cape. Thirteen ships were sunk in the first four days of the offensive. Whilst maintaining anti-submarine patrols at the entrances to South African

14 Roger Williams, “Commodore J. Dalgleish CBE,” in Naval Digest Number 13 (Durban: Just Done Publications, 2008), 11.

15 The South African Naval Forces in World War 2: 1939-1945 (Simon's Town: SA Naval Museum)1.

16 The critical importance of the Cape sea route again would be highlighted during the post-war Arab-Israeli conflicts which led to the closure of the Suez Canal for long periods. 
ports, SANF ships also took part in coastal anti-submarine and convoy operations and were responsible for rescuing many survivors from torpedoed ships throughout the offensive. Despite the enormous distances between Germany and South Africa, German records show that no fewer than 29 U-boats operated in South African waters at various times during the war. ${ }^{17}$ Indeed, during the Second World War, some 133 ships totalling 743,544 gross registered tons were sunk within 1000 nautical miles of the South African coast by axis-submarines, whilst only three German U-boats were destroyed during this offensive.

Two SANF escort groups, under British operational control, operated in the Indian Ocean between Durban, Mauritius and Kilindini in East Africa between 1943 and 1945, and in early 1945, SANF representation in the war was widened by the dispatch of two vessels to Far Eastern waters. In addition to this, the SANF also manned two British River-class frigates in the Indian Ocean during the closing stages of the war.

The most significant development in the wartime SANF occurred in mid-1944 when the British Admiralty transferred three new Loch-class anti-submarine frigates still under construction to the Union government in recognition of the service given by South African volunteers to the war at sea. In return, the South African government agreed to second 3,600 personnel to the Royal Navy over the next twelve months. The first two units, Good Hope and Natal, were employed in British waters and in the North Atlantic during the final days of the war in Europe. Natal, which had the distinction of sinking a German U-boat whilst on trials - the only Allied ship on record to achieve this unique feat - also served in Eastern waters during the closing stages of the war against Japan. The third and final unit, Transvaal, which arrived in Cape waters in July 1945, commissioned too late to serve in either theatre.

In addition to manning vessels of the SANF, 786 officers and 2,151 ratings were seconded to the Royal Navy. As a result, South African officers and ratings served in just about every type of ship and took part in nearly every major naval operation of the war. Their individual achievements were impressive. Some took part in the X-craft attack on the German battle-cruiser Tirpitz and many also served in the Fleet Air Arm. A number made the ultimate sacrifice. Significant South African losses were sustained when the cruisers Neptune and Gloucester were lost in the Mediterranean, and the Dorsetshire, Cornwall and Hermes were sunk by the Japanese in the Indian Ocean.

Although South Africa had no navy of her own at the outbreak of the Second World War, the establishment of an efficient sea-going force and the rapid expansion of the SANF during the conflict was quite remarkable. South Africa's 'little ships', which were awarded 129 battle honours, earned an enviable reputation both in local waters and overseas, and South African sailors established a proud fighting tradition. At the peak period of hostilities in 1944, the South African fleet consisted of 78 vessels, and by the end of hostilities in 1945, the SANF had a strength of 8,090 officers and ratings. A total of 324 members of the SANF were killed in action or died in service, and 244 awards for 
gallantry or distinguished service were bestowed on South Africans. ${ }^{18}$

\section{Immediate Post-War Period}

Towards the end of the war, the Union government decided to retain a permanent sea-going fleet for the defence of South Africa after hostilities ended. A key lesson from the war was that South Africa needed a navy of its own under independent command as the Union could no longer rely on others and would need to contribute to its own maritime protection and freedom of the sea for trade. ${ }^{19}$ This decision was implemented on 1 May 1946 when the combat-tested SANF was reconstituted as a permanent part of the UDF, with an authorised establishment of 60 officers and 806 ratings mainly filled by 'hostilities only' volunteers awaiting demobilisation. With headquarters at HMSAS Bonaventure in Cape Town and newly-promoted Commodore James Dalgleish as its director, the SANF immediately set about building up its strength as an anti-submarine, convoy protection and mine countermeasures force largely based on British strategy and practice.

Following the closure of wartime SANF establishments at the various ports, and the disposal of requisitioned vessels and ships borrowed from the Admiralty, the SANF was wound down to 17 ships. The immediate post-war fleet consisted of the three new Loch-class frigates, two Bar-class boom defence vessels, a controlled minelayer and eleven harbour defence motor launches, whilst two modern Algerine-class ocean minesweepers and a Flower-class corvette, which was converted into a hydrographic survey vessel, were purchased from Britain in 1947. With the acquisition of these three ships the authorised establishment of the SANF was increased to 75 officers and 913 ratings. By this time the service was headed by Commodore F.J. Dean, OBE, who had continuously served in the SANF and its predecessors since 1928. Despite his British background, his approach was wholly South African, and he is well remembered for saying that "unless the South African Navy is a purely South African flower, it will never grow." 20 Indeed, less than a year after the war's end, a distinctly South African naval ensign replaced the British White Ensign which South African naval vessels had worn since the formation of the South African Naval Service in 1922.

With the end of hostilities, the four pre-war RNVR(SA) bases, which were renamed SA Naval Reserve Bases, reverted to their former role of training members of the Naval Citizen Force, and in 1948 a fifth reserve base was established in Johannesburg. Also during 1948 SANF Headquarters moved to Pretoria whilst the fleet and all other personnel moved from Cape Town and the training establishment at Saldanha Bay to the new naval base at Salisbury Island in Durban, which had been intended as a major fleet repair base for the Royal Navy following the fall of Singapore in 1942. This extensive base, with its quays, workshops, training, administration and accommodation blocks all in one compact area, had been completed too late to be of use

18 Du Toit, South Africa's Fighting Ships, 32.

19 Bennett \& Söderlund, South Africa's Navy, 7.

20 J. Johnson, “Commodore F.J. Dean,” in SA Navy News Vol II No 101983 (Simon's Town: SA Navy), 7. 
during the Second World War.

Next in the expansion of the navy was the purchase of a relatively new war-built W-class destroyer from the Royal Navy which was commissioned into the fleet as HMSAS Jan van Riebeeck in 1950. On 1 January 1951 the title South African Naval Forces was replaced by the simpler South African Navy (SAN), and the Director SANF became the Naval Chief of Staff. Six months later the South African Corps of Marines was formed from the long-established Coast Garrison Artillery and Anti-Aircraft Regiments, and Brigadier Pieter de Waal, CB, CBE, who had previously headed the army, was appointed Naval and Marine Chief of Staff, ironically becoming the first South African to head the South African Navy. At the same time, Commodore Dean was appointed to the new post of Commodore Commanding Coastal Command, with responsibility for running the operational side of the navy from his new headquarters at Youngsfield in Cape Town. The controversial appointment of an army officer to head a sea service was further aggravated by the decision of the Chief of the General Staff at the time, for some unknown reason, to obtain the services of a senior Royal Navy officer on secondment to assist Brigadier de Waal in administering the navy. Following a strong written protest from Commodore Dean (supported by Brigadier de Waal) that the introduction of a senior Royal Navy officer on top of his appointment would "have a great adverse effect on morale,"21 the CGS changed his mind.

By the beginning of 1952 the SAN had grown to 132 officers and 1,499 men, and in June that year the prefix of SA naval vessels was changed from HMSAS to SAS as growing Afrikaner nationalism gripped South Africa following the 1948 election of a National Party government, which come to power on its platform of apartheid or separation of the races in South Africa. Despite the new government's attempts to change its British traditions and even ranks, strong links with the Royal Navy ensured that the SAN remained largely 'English' in character, although the requirement to be bilingual became more and more prominent.

On 1 December 1952 Temporary Commodore Hugo Biermann, OBE, at the relatively early age of 36 was appointed as Acting Naval and Marine Chief of Staff, the first South African naval officer to head the SAN, superseding a number of Englishspeaking officers superior in rank to him. The apolitical, bilingual, capable and modest Biermann, who had served at sea in the SANF with distinction both during the Second World War and in the immediate post-war years, was to handle this challenge with great sensitivity and humility. He ably led the SAN for almost 20 years as the service steadily grew. He progressed in rank, finally becoming a four-star admiral in 1972 and the only SAN officer to date to head the South African armed forces. He is widely regarded as having created a truly independent South African Navy, retaining the customs and traditions of the Royal Navy whilst blending this with South Africa's own distinctive culture and heritage. ${ }^{22}$

21 Goosen, South Africa's Navy The First Fifty Years, 115.

22 Roger Williams, “A biography of Admiral H H Biermann, SSA SD OBE," in Naval Digest Number 9 (Simon's Town: Naval Heritage Society of South Africa, 2003), 30. 
A year later, a second W-class destroyer, SAS Simon van der Stel, was purchased from Britain and commissioned into the fleet, and a Ford-class seaward defence boat (SDB) was ordered for the protection of Durban harbour. In 1955, as the old coastal defences became obsolete, it was determined that the Corps of Marines could no longer fill a useful role in the defence of the country. It was consequently disbanded on 28 April 1955, with the coast artillery section being incorporated into the navy and the anti-aircraft section transferring back to the army. At the same time the title of the head of the Navy reverted back to Naval Chief of Staff, which it remained until 1 December 1965, when it was changed to Chief of the Navy.

\section{The Cold War}

With the onset of the Cold War and the developing conflict in the Middle East, which threatened the alternate sea route via the Suez Canal, the strategic importance of the British naval base at Simon's Town gained in importance. After protracted negotiations, and at times considerable reluctance on the part of the British government, ${ }^{23}$ a series of letters collectively referred to as the "Simonstown Agreement" were finally exchanged by the South African and British governments in 1955. The Agreement established a special relationship between the Royal Navy and South African Navy, and served as a very useful force multiplier. It provided for the transfer of the naval base at Simon's Town to South African control and the significant expansion of the SAN and maritime elements of the South African Air Force to assume an increasing responsibility for the collective defence of the vital sea route around the Cape of Good Hope. Signed at a time of increasing Soviet expansionism and influence, with Britain still facing significant post-war financial hardships and South Africa taking an increasingly nationalistic and anti-communist path, the agreement on defence cooperation was mutually beneficial to both parties.

Based on the experience of two world wars, and in the light of the increasing Soviet threat, the expansion of the SAN (then very much seen as an operational extension of the Royal Navy) was almost exclusively focussed on the acquisition of anti-submarine and mine countermeasures capabilities. It resulted in the rapid expansion and development of a small but highly professional, efficient and well-equipped Commonwealth navy which was well able to train and effectively take its place alongside the RN and other Commonwealth and Allied navies during the Cold War.

From a British perspective, the Agreement was particularly favourable. Although it met the South African government's strong desire to have the last British military base on South African soil transferred to South African control after a 150-year British presence, it importantly provided for the continued use of the base at Simon's Town by

23 See UK National Archives (UKNA), PREM 11/1765, Royal Navy Base at Simonstown, Defence Committee, Memorandum by the Secretary of State for Commonwealth Relations D(51)4, 18 December 1951; and G.R. Berridge and J.E. Spence, "South Africa and the Simonstown Agreements," in J.W. Young (ed), The Foreign Policy of Churchill's Peacetime Administration 1951-1955 (Leicester: Leicester University Press, 1988). Readers will note that the spelling in the agreement differs from that of the geographic place name. 
Britain and its allies in peace and war, even in a war in which South Africa was not involved. It significantly increased commonality and interoperability between the two navies, and in time of war placed South African maritime forces under the command of the British Commander-in-Chief South Atlantic, who remained at the Cape long after the signing of the Agreement. ${ }^{24}$

From a financial perspective, while Britain retained full access to Simon's Town, the Agreement imposed considerable obligations on the South African government and absolved Britain from the costly upkeep and modernisation of the base and other maritime facilities at the Cape, including access to strategic naval communications, fuel stocks and over-flying rights. Finally, from an economic perspective, the Agreement greatly benefited British industry with significant South African orders following for warships, helicopters and maritime patrol and strike aircraft.

As a result, the developing SAN vacated its base at Salisbury Island in Durban and moved to Simon's Town, and on 2 April 1957 the British flag was finally lowered for the last time at HM Naval Dockyard Simon's Town. Among the most important administrative changes which followed the Agreement was the move of the Naval Chief of Staff and Naval Headquarters from Pretoria to Simon's Town. The naval base at Salisbury Island was closed down in due course once the move to Simon's Town had been completed.

The Simonstown Agreement initiated an era of unprecedented expansion and modernisation of the fleet. Within the terms of the Agreement, South Africa duly purchased a further four Ford-class seaward defence boats, ten Ton-class coastal minesweepers, a Type 15 anti-submarine frigate, and three Modified Type 12 antisubmarine frigates from the United Kingdom between 1955 and 1963. ${ }^{25}$ The Type 12 frigates, known as the President class, were particularly notable as the first major warships ordered and built specifically for the SAN. These new vessels formed the $10^{\text {th }}$ Frigate Squadron and the minesweepers formed the $147^{\text {th }}$ Minesweeping Squadron, essentially the South African contribution to a wider British and Allied Cold War presence in the South Atlantic and Southern Indian Ocean.

In addition to these newly acquired ships, which virtually trebled the size of the fleet, many of the older vessels were also upgraded locally. Although the Loch class with their relatively slow speed of 19.5 knots were no longer able to effectively counter fast modern submarines, the destroyers possessed the required speed margin and were extensively upgraded to RN Type 16 configuration between 1962 and 1966, including the unique ability to operate two Westland Wasp anti-submarine helicopters each, which made them most useful anti-submarine units. At the same time, the SAAF acquired Avro

24 The Agreement established a strategic zone approximating to the British South Atlantic Station, including the Mozambique Channel, in which both the RN and SAN would operate under the operational authority of the British Commander-in-Chief South Atlantic. Within this zone lay a South African Area which remained the direct responsibility of the SAN.

South Africa had intended to buy six frigates, but because of rising costs, only four were purchased, whilst the number of seaward defence boats acquired was increased from four to five. 
Shackleton long range maritime patrol aircraft from Britain in 1957 to replace its aging Sunderlands, Westland Wasp helicopters in 1964 for operating from the converted Wclass destroyers, and Hawker Siddeley Buccaneer maritime strike aircraft in 1965.

In the 1960s, as the National Party's racial policies began to create more and more ill-will abroad, South Africa was subjected to a process of increasing isolation from the international community. When South Africa became a republic in 1961 and left the British Commonwealth, numerous African states were in the process of achieving independence. These states began to call for an arms embargo against the new republic and the cancellation of the Simonstown Agreement. The threat of Communism and Communist-inspired insurgency in Africa also appeared to be growing. It was against this background of growing isolation and an increased external threat that the South African government decided to drastically increase the size and improve the readiness and efficiency of the South African Defence Force (SADF) and develop greater selfsufficiency in weapons and munitions production. ${ }^{26}$

Whilst the original concept of the SAN had been one of 'close' defence with the backing of allies, it was becoming increasingly apparent that an independent force, capable of intercepting any possible seaward attack on South Africa at a distance, was required. In essence this was the fundamental point at which the SAN came of age and began moving from being a fleet to a fully-fledged navy in its own right.

Following the election of a Labour government in the United Kingdom in 1964, Britain refused to supply further arms to South Africa. Whilst this ban included any new orders for maritime aircraft and naval vessels and equipment, the British government was still prepared to honour existing contracts and to provide spares within the terms of the Simonstown Agreement. In spite of its determination not to enter into arms sales with South Africa, the British government nevertheless still considered the Simonstown Agreement to be a strategically important treaty, which as such remained in force, and links between the $\mathrm{RN}$ and SAN remained strong. ${ }^{27}$ Effective training and strong leadership at sea, linked to the acquisition of the new frigates, resulted in a very professional and effective naval force, and combined exercises and weapons training periods continued between the two navies on a regular basis, the South African ships performing with great credit, reflecting the high standards of operational efficiency achieved.

At the same time as the SAN developed its expertise at sea, advantage was taken of the training that so many of the officers and senior ratings had gained whilst attending specialist training in the United Kingdom to develop a local training capability based on specialist naval warfare schools which were established in Simon's Town. Similarly, the ability to effectively manage the Naval Dockyard at Simon's Town and the ability to train its personnel to international standards meant that the SAN could very capably support and modernise its fleet. As a result, when South Africa's isolation began to really impact on the SAN, the survival of a professionally effective service was assured by its ability to

26 See Magnus Malan, My Life with the SA Defence Force (Pretoria: Protea Book House, 2006), 148-155.

27 UKNA, FCO 45/1613, "The Importance of the Simon's Town Agreement." 
carry out its own training and support. ${ }^{28}$

As most African ports were now closed to SAN vessels for refuelling, it became necessary to acquire a fleet replenishment vessel to maintain the SAN's reach and ability to effectively operate in the South Atlantic, Southern and Indian Oceans. As it was becoming increasingly difficult to obtain such a vessel from abroad, a commercial tanker was purchased in 1965 and converted into a fleet replenishment vessel at Durban. She was commissioned as SAS Tafelberg in August 1967, and immediately became the largest and one of the most useful vessels in the fleet. ${ }^{29}$

Another change occurred in October 1966 with the establishment of a co-located Maritime Headquarters at Youngsfield where the British C-in-C South Atlantic maintained his headquarters. As a result, the Chief of the Navy assumed the additional appointment of Commander Maritime Defence (COMMARDEF), the Operations Directorate of the SAN moved to Youngsfield, and the operational control of Maritime Group SAAF passed to the new headquarters, which became responsible for the command and control of all maritime forces allocated for operations in the South African Area.

Following the closure of the British South Atlantic Command on 12 April 1967 as part of Britain's cut back in her overseas defence commitments, and the revision of the Simonstown Agreement, a much smaller British organisation under a commodore, known as the Senior British Naval Officer South Africa (SBNOSA), was established at HMS Afrikander at Youngsfield. ${ }^{30}$ At the same time, the last remaining RN frigate stationed at Simon's Town returned to the United Kingdom and the C-in-C's Cold War responsibilities with regard to the Cape sea route were transferred to COMMARDEF, and the SAN would now increasingly operate as a navy in its own right rather than as part of a British commanded fleet for the defence of the Cape sea route. Most of the other provisions of the Agreement, however, remained unchanged.

One of the most important moves to improve the fighting efficiency of the fleet and provide South Africa with a credible maritime deterrent was taken during the mid1960s with the decision to acquire submarines. Although South African interest was focussed on the modern and highly successful Oberon class, this interest was short lived. Following the election of the Labour government in Britain in 1964, South Africa decided instead to approach France, which had recently developed the small, moderately-priced but highly-capable Daphne-class hunter-killer submarine. An order was subsequently placed with a French yard in 1967 for the construction of three of these submarines, and the first boat, SAS Maria van Riebeeck, was commissioned in July 1970, whilst the last unit arrived in Simon's Town in June 1972.

Although South Africa had not previously operated submarines, and the general consensus amongst foreign naval observers at the time was that the SAN would not be

28 Bennett \& Söderlund, South Africa's Navy, 33.

29 Goosen, South Africa's Navy the First Fifty Years, 156.

30 UKNA, FCO 25/656 JS 10/10, "Withdrawal of the British Commander-in-Chief from South Africa." 
capable of operating them effectively on its own without direct support and advice from abroad for at least a decade, they were soon proven wrong. The determination of the SAN to quickly and effectively grasp submarine operations was underpinned by the availability of experienced dockyard management and technical staff in the Simon's Town Naval Dockyard, some of whom had submarine refit experience. The result was that the SAN was able to take into service, operate and maintain these submarines extremely effectively in a short space of time. ${ }^{31}$

At the same time the three President-class frigates were progressively upgraded by the Simon's Town Naval Dockyard to operate Wasp helicopters, a combined torpedo recovery vessel and diving tender was built in Durban, and a new Hecla-class survey ship (the last naval vessel built in the United Kingdom for the SAN) was acquired. The growth of the fleet also progressively led to major expansion within the Simon's Town Naval Dockyard, and the Salisbury Island naval base at Durban was also progressively reactivated and modernised from 1972.

In July 1970 the newly elected Conservative government in Britain stated its intention to rebuild the United Kingdom's "vital defence interests" in South Africa and to resume limited arms sales to help the Republic defend the sea route around the Cape in accordance with the spirit of Britain's obligations under the Simonstown Agreement. ${ }^{32}$ However, the Labour opposition stated that any South African orders placed in the United Kingdom would be cancelled if they were subsequently returned to office.

Because of the complications of ordering new frigates from Britain in the early1970s, it was announced in 1971 that negotiations were proceeding with firms in Europe for the design of six missile-armed corvettes, four of which were to be built overseas, whilst the remainder were to be built in South Africa. Orders were subsequently placed with a Spanish shipyard with Portugal acting as intermediary, but political developments in the Iberian peninsula in 1974 led to the cancellation of the project. ${ }^{33}$

In 1973, Maritime Headquarters moved to a sophisticated new above-ground administrative building and underground operational facility in the mountains at Silvermine outside Cape Town. By 1975 the post of Commander Maritime Defence had been abolished and a Naval Operations Command, supported by the SAAF's Southern Air Command, responsible for all maritime air operations, was formed at Silvermine to continue the close joint co-operation between the SAN and SAAF.

Although regular combined exercises with the RN and RAF continued unabated (and indeed markedly increased throughout the early-1970s whilst a Conservative government was in power in Britain) and South African personnel continued to attend RN courses, worsening relations between the two signatories of the Simonstown Agreement following the return of a Labour government in 1974 finally culminated in the

31 Bennett \& Söderlund, South Africa's Navy, 33.

32 Edward Heath, The Course of My Life (London: Hodder and Stoughton, 1998), 319.

33 The design for these 1,380-ton ships was based on the German Blohm and Voss designed Portuguese Jao Coutinho class. All four ships intended for South Africa were subsequently commissioned into the Portuguese Navy. 
termination of the Agreement on 16 June 1975. The subsequent withdrawal of SBNOSA and the closure of HMS Afrikander at Youngsfield in February 1976 finally closed the chapter on 180 years of British naval presence in South Africa, and effectively ended the traditionally close relationship between the SAN and RN, and by extension its window into NATO.

The subject of intense political controversy in Britain, within the Commonwealth and at the United Nations for much of its existence, the fact that the Agreement continued for twenty years is remarkable. Although it was finally terminated long after South Africa had left the Commonwealth and at a time when Britain was withdrawing from East of Suez and South Africa was becoming increasing isolated because of its apartheid policies, the Agreement remains an excellent practical example of Commonwealth naval co-operation and interoperability.

\section{Going it Alone}

Following the termination of the Simonstown Agreement, the SAN was forced to abandon its Cold War role as 'Guardian of the Cape sea route', and from 1978 concentrated entirely on the protection of South Africa's coastline and maritime interests. The position taken by South Africa was that the responsibility for defending the Cape sea route rested on the shoulders of the West and not on the Republic, but that South African facilities would be made available to them, if they so requested, and if this was in South Africa's national interest. ${ }^{34}$

With the voluntary arms boycott increasingly reducing existing lines of supply, an order for three fast Reshef-class missile armed strike craft was placed with Israel in late 1974, whilst two A69-class corvettes and two Agosta-class submarines were subsequently ordered from France in 1975.

In 1976 Naval Headquarters moved back to Pretoria to facilitate closer joint coordination between the various arms of the SADF. This move, however, resulted in the Navy accepting a most unsuitable and staff-intensive organisational structure which drew heavily on the SAN's limited resources of skilled personnel. This unsustainable structure was to last until $1986 .^{35}$

In February 1977 the Chief of the SADF effectively curtailed the SAN's blue water role by limiting it to: monitoring, controlling and protecting the interests of the Republic in its territorial waters and EEZ; discouraging and deterring maritime aggression against South Africa; and undertaking operations supporting the achievement of objectives on land. ${ }^{36}$ The SAN's remaining blue water capabilities were dealt a further blow by the imposition of an all-embracing and unexpected mandatory arms embargo which was tabled and accepted by the United Nations in November 1977. Whilst the three Israeli-built strike craft were delivered in 1977, Paris cancelled the sale of the

34 SA Navy, VSH 307/1/3 (G) Enclosure 1 to letter dated 5 November 1980 discussing the RSA's position regarding defence of the Cape sea route. 
corvettes and submarines, leaving the SAN with no overseas source for new corvettes and submarines. The embargo also had a significant impact on training. Although all training in the United Kingdom had ceased with the termination of the Simonstown Agreement in 1975 and had been repatriated to South Africa, training had continued in France. This, too, now came to an end.

As a result of the embargo, the SAN was left with an elderly fleet of antisubmarine vessels which could not be replaced except through the costly option of local development and construction. Undeterred, the SAN was determined to make the best of what it had. Indeed, the SAAF faced a similar problem without a replacement for their ageing Shackleton long range maritime patrol aircraft. To make matters worse, with the increasingly landward focus of South African military operations, the SAN's budget was significantly reduced. From its previous average of around 18 percent of the Defence budget, the naval portion of the budget was reduced to less than 9 percent by $1979 .{ }^{37}$

Other developments during this period, in line with its increasing role to support land operations, included the reappearance of a Marine Branch primarily for harbour protection and counter-insurgency operations. In addition, the replenishment vessel Tafelberg was extensively upgraded to support amphibious operations. This conversion allowed her to carry a company-strength landing force, two medium helicopters and up to six fast assault craft equipped with bow ramps as well as the addition of a small hospital.

Although the sale of all three President-class frigates had been contemplated in light of the imminent arrival of the new corvettes from France, these plans were soon discarded and the decision was made to upgrade and retain two of them in operational service until new replacement corvettes could be locally built. However, following the tragic loss of President Kruger, which sank after a collision with the Tafelberg in February 1982, plans to expend the stripped-out President Steyn as a target were immediately suspended whilst the possibility of reconstructing her and returning her to operational service was investigated. Meanwhile, President Pretorius, the last operational Type 12 frigate continued in service until late 1985 when she was finally placed in operational reserve at Simon's Town for manpower and economical reasons. With her reduction to reserve status, the SAN lost its last operational anti-submarine frigate, and the dominant role that these frigates had played in the SAN came to an end. Considering that the SAN had been a very proficient anti-submarine force since the 1940 s, this was a particularly significant event.

The arms embargo did, however, see a spectacular period of growth in South Africa's domestic armaments industry, including the local construction of six Ministerclass missile armed strike craft between 1978-82, similar to the three supplied by Israel, as well as the construction of new German-designed River-class minehunters to supplement and eventually replace the venerable Ton-class mine countermeasures vessels, and the construction of the locally-designed replenishment vessel SAS Drakensberg. These programmes produced substantial technical, economic and strategic benefits, and most important of all placed the country firmly on the road to building submarines and corvettes locally to meet the SAN's future needs. Furthermore, the era of

37 Bennett \& Söderlund, South Africa's Navy, 35. 
isolation obliged South Africa to develop a wide range of indigenous naval technologies which are now widely fitted in its submarines and surface ships.

\section{Independent Regional Operations}

Not long after the Simonstown Agreement was terminated in 1975, South Africa was drawn into operations in support of anti-marxist forces in Angola following the collapse of Portuguese rule in its former colony and the deployment of surrogate Soviet forces in the form of Cuban troops to support the opposing Marxist forces. The frigates President Kruger and President Steyn, supported by the fleet replenishment vessel Tafelberg, took part in Operation Savannah, the South African incursion into Angola between October 1975 and January 1976.

During the ensuing decade and a half, as the so-called "Border War" escalated and South Africa increasingly carried out operations inside both Angola and Mozambique, special operations significantly increased in importance and by the end of the 1970s the Navy was increasingly employed transporting and inserting special forces as well as conducting reconnaissance and intelligence missions. ${ }^{38}$

This new niche role in direct support of land operations, using the capabilities of the ships and submarines it had at its disposal, gave the Navy joint 'kudos' and was to prove a life-line for the marginalised SAN. Using the strike craft far beyond their design specifications, special forces teams were landed behind the lines on beaches and reembarked and brought home after completing their missions. For some of the more distant and covert operations the SAN demonstrated how rapidly and how effectively it had mastered the complex and difficult task of operating submarines by using them to insert and recover small teams. Once again, although this was not a task for which the Daphne-class submarines had been designed, they were used most effectively in this role. ${ }^{39}$

\section{Changing Fortunes}

The isolation years and the period of the "Border War" from the mid-1970s saw the SAN again fighting for its survival with significant reductions in budget and large reductions in personnel. ${ }^{40}$ As part of a cost-cutting force rationalisation programme, principally to free up funding for land operations, a number of ships were approved for disposal in 1985. At the same time, the increasingly cost-strapped SAN's unsustainable command structure was reorganised and steam-lined.

As a result of much reduced defence commitments and the political shift away from security to welfare in the lead up to full democratic elections, a further extensive rationalisation programme for the entire SADF, involving drastic cut-backs and curtailments, was announced in January 1991. This painful restructuring and rationalisation process necessitated the retrenchment of about 2,400 uniformed and

38 Bennett \& Söderlund, South Africa's Navy, 35.

39 Bennett \& Söderlund, South Africa's Navy, 35.

40 Bennett \& Söderlund, South Africa's Navy, v. 
civilian naval personnel of all ranks which had significant impact on the SAN.

Whilst the SAN had hoped to supplement and eventually replace their Daphneclass submarines with locally constructed boats based on the German Type 209 design, this project was shelved not long afterwards mainly for budgetary reasons. ${ }^{41}$ Similarly, attempts to locally build four German-designed Meko corvettes to replace the four oldest strike craft were also shattered in August 1991 as steel for the first vessel was about to be cut. As a result, the SAN had to be content for the time being with the three upgraded Daphnes and the Minister-class strike craft which had provided excellent service but which were not ideally suited for sustained open ocean operations in the notorious waters surrounding Southern Africa.

The SAN was again at the crossroad of survival as a viable and effective service. Although many believed that it was unlikely to survive, this all changed with the coming of full democracy in South Africa and the realisation that the nation was indeed a maritime nation in need of a strong navy. ${ }^{42}$

In the lead-up to the first fully-democratic elections in 1994, it became apparent that there was growing support within the African National Congress (ANC) political leadership for the development of a balanced blue water fleet. Following the election of an ANC government, and South Africa's return to the Commonwealth, the SAN's immediate priority was to obtain funding for the long delayed surface combatant capability, capable of sustained open ocean operations in its maritime area, and in due course a replacement for the Daphne-class submarines.

Whilst there was strong support for the navy which emerged from the apartheid years with a good reputation, there were many urgent nation-building needs to be met from limited government funding. The new government, not wishing to approve a project for which they did not fully understand the requirements or the long term implications, refused to sanction the acquisition of corvettes, preferring instead to address the requirement for both corvettes and submarines as part of a broader defence review process which commenced in early 1996. The Defence Review involved significant public consultation and produced a final report in May 1997 which allowed the newly renamed South African National Defence Force (SANDF) to go forward with full national consensus and legitimacy. ${ }^{43}$ The implications of the Defence Review for the SAN were significant. With its force structure plans finally endorsed by government, the SAN was able to commence a total regeneration of its sea-going capability and progress the acquisition of new frigates and submarines, which was to be achieved in a remarkably short space of time. ${ }^{44}$

In addition to these acquisitions, the post-apartheid SAN had to make rapid

41 At the time of cancellation the project had progressed to the stage where specialist infrastructure had been developed in Durban, technology had been brought in and long leadtime equipment was already on order.

42 Bennett \& Söderlund, South Africa's Navy, v.

43 Bennett \& Söderlund, South Africa's Navy, 52-3.

44 Bennett \& Söderlund, South Africa's Navy, 59. 
provision for achieving greater gender, cultural and demographic equity goals. Although members of the coloured and Indian communities had served alongside their white colleagues in the SAN for a number of years, and the SAN had achieved some remarkable successes in helping to bridge the racial divide that existed in the country, it was not until 1990, when service in the Navy was opened to volunteers from all South African communities, that black officers and ratings were first recruited. This requirement, which included the integration of former military wing members of the liberation forces who volunteered to join the Navy, placed an enormous strain on the whole naval structure, especially the training establishments. As the SAN transformed, great care also had to be taken to ensure that the necessary skills and expertise, required to effectively operate and maintain fully operational ships and submarines, was not lost or diminished. ${ }^{45}$

At the same time, the entire SANDF was undergoing a major transformation. As part of this process, the SAN, together with the other services, became a force provider to the Chief of Joint Operations and its entire command structure was again reorganised. The new SAN structure resulted in a single entity, Fleet Command, whilst a much reduced Naval Headquarters provided policy and direction.

Whilst this consolidation of transformation was taking place, Cabinet approved the acquisition of four MEKO A-200 SAN frigates and three Type 2091400 Mod RSA diesel submarines from Germany in 1999. This ushered in a new era which would stretch declining resources but would put the SAN back in the international field of credible navies. ${ }^{46}$

\section{The South African Navy of Today}

The current South African Navy with its compact but balanced fleet of modern frigates and submarines, together with its minor war vessels and support ships, is acknowledged as being one of the best small navies in the world. Transformation has allowed the SAN, now lead by Vice-Admiral Mudimu, the first black South African Chief of the Navy, to function more efficiently and mirror the demography and broad cultural mix of the population, and it has clearly emerged from the period during which the country's international isolation and the traditionally excessive landward focus of South African politicians and defence planners cost the SAN some critical operational capabilities.

With its restored blue water capability, the SAN is once again a regular participant in international exercises and holds regular passage exercises with visiting warships. South Africa has a number of bi-lateral Navy-to-Navy relationships with other nations and international groupings. In some cases these are the basis for international exercises such as the bi-annual Exercise ATLASUR with the navies of Argentina, Brazil and Uruguay and the increasingly complex biannual GOOD HOPE series of exercises with the German Navy and Air Force. In May 2008 the first combined exercise under the

45 See Bennett \& Söderlund, South Africa's Navy, passim.

46 Bennett \& Söderlund, South Africa's Navy, 59. 
IBSA (India, Brazil and South Africa) agreement, Exercise IBSAMAR, took place in Cape Waters. ${ }^{47}$

The SAN has also spearheaded naval diplomacy initiatives and is actively building links with the navies of other African nations to enable Sub-Saharan Africa to meet the maritime challenges it faces. ${ }^{48}$ The SAN is actively involved in the Southern African Development Community (SADC) through its Standing Maritime Committee (SMC). South Africa is also closely involved in United Nations (UN) and African Union (AU) activities aimed at bringing peace and stability to the wider African continent. This includes providing maritime forces for $\mathrm{UN}$ and AU sanctioned peace operations, general disaster relief missions, or to come to the assistance of those states unable to police their own waters effectively. ${ }^{49}$

\section{Conclusion}

The South African Navy, as one of the original dominion navies, has a long tradition and a proud record of achievement in protecting South Africa's maritime sovereignty and interests, and contributing forces to wider conflicts and contingencies over many years. Since its formation in 1922 it has evolved and developed into what it is today, and it can currently claim to be the most efficient and best-equipped navy on the entire African continent and arguably one of the best small navies in the world, with a compact, well-balanced and well-supported fleet. It has, however, been a long and at times, painful journey, both in terms of its strength and its role, as the service has grown and contracted disproportionately over the years depending on the whims of government, the vagaries of the economy, and indeed the perceptions of the nation.

47 Bennett \& Söderlund, South Africa's Navy, 9.

48 Helmoed-Römer Heitman, "Challenging Adversity," in Jane's Defence Weekly, 47:36, 8 September 2010, 21.

49 Bennett \& Söderlund, South Africa's Navy, 9. 